\title{
Monthly Variability of Chlorophyll- $\alpha$ Concentration in Persian Gulf Using Remote Sensing Techniques
}

(Kevariabelan Bulanan Kepekatan Klorofil- $\alpha$ di Teluk Parsi Menggunakan Teknik Penderiaan Jarak Jauh)

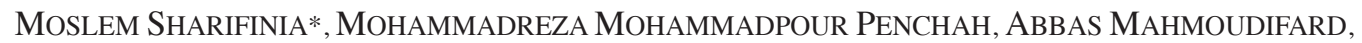 \\ ABOLHASAN GHEIBI \& ROHALLAH ZARE
}

\begin{abstract}
During the last two decades, large-scale high biomass algal blooms of the dinoflagellate Cochlodinium have occurred frequently. Prior to 1990, blooms had been primarily reported in Southeast Asia. Since then, time blooms have expanded across Asia, Europe and North American. A multi-spectral classification and quantification technique is developed for estimating chlorophyll-a concentrations. In this study, we explored the use of Sea-viewing Wide Field of-view Sensor (SeaWiFS) satellite data in studying the spatio-temporal changes in chlorophyll-a concentration in Persian Gulf. In addition, the present study focuses on the temperature, dissolved oxygen, salinity, $p H$ and nutrient concentrations during the red tide phenomenon. The resultant chlorophyll-a concentration images derived from SeaWiFS satellite data give an indication of the monthly spatial variation in chlorophyll- $\alpha$ concentration from 2008 to 2009. Variability of chlorophyll- $\alpha$ plot from September 2008 to May 2009 in Persian Gulf showed that September 2008 had the lowest value (1.57 \pm 0.14 $m g \mathrm{~m}^{-3}$ ) than other years except May 2009, then tended to increase up to January 2009 (Highest value: $7.47 \pm 1.67 \mathrm{mg}$ $\left.\mathrm{m}^{-3}\right)$, then a slow decrease up to May 2009. The result showed all water physicochemical parameters measurement insitu $(\mathrm{DO}$ and $\mathrm{pH})$ and ex-situ $\left(\mathrm{NO}_{3}\right.$ and $\left.\mathrm{PO}_{4}\right)$, were varied among the different months. The highest and lowest values of these parameters were recorded in September 2008 and May 2009, respectively. After occurrence of the red tide, nutrient concentration $\left(\mathrm{NO}_{3}\right.$ and $\left.\mathrm{PO}_{4}\right)$, dissolved oxygen and $\mathrm{pH}$ were reduce compared to before this phenomenon. Compare mean between various months' showed significant differences for temperature records among the months of study ( $p \leq 0.05)$. Lowest and highest temperature recorded were in February 2009 and September 2008, respectively, but no significant differences were found in salinity $(p \geq 0.05)$. This study showed that SeaWiFS satellite data provide useful information on the spatio-temporal variations in Persian Gulf, which is useful in establishing general trends that are more difficult to determine through routine ground measurements.
\end{abstract}

Keywords: Bloom; chlorophyll- $\alpha$; fish mortality; Persian Gulf; SeaWiFS

ABSTRAK

Sepanjang dua dekad yang lalu, ledakan alga biojisim berskala dinoflagellate Cochlodinium telah berlaku dengan kerap. Sebelum tahun 1990, ledakan selalunya dilaporkan di Asia Tenggara. Sejak itu, masa ledakan telah merebak ke seluruh Asia, Eropah dan Amerika utara. Pengelasan pelbagai tatacara dan teknik mengkuantifikasi dibangunkan untuk menganggar kepekatan klorofil- $\alpha$. Dalam kajian ini, kami mengkaji penggunaan sensor pandangan laut bidang luas pandangan (SeaWiFS) data satelit dalam mengkaji perubahan spatio-temporal dalam kepekatan klorofil- $\alpha$ di Teluk Parsi. Di samping itu, kajian ini tertumpu kepada suhu, oksigen terlarut, kemasinan, kepekatan pH dan nutrien semasa fenomena pasang-surut merah. Kepekatan klorofil- $\alpha$ imej terhasil yang diperoleh daripada SeaWiFS data satelit memberi petunjuk variasi bulanan reruang dalam kepekatan klorofil- $\alpha$ dari 2008 ke 2009. Kebolehubahan plot klorofil- $\alpha$ dari September 2008 hingga Mei 2009 di Teluk Parsi menunjukkan bulan September 2008 mempunyai nilai terendah $\left(1.57 \pm 0.14 \mathrm{mg} \mathrm{m}^{-3}\right.$ ) berbanding tahun lain kecuali Mei 2009 yang kemudian terus meningkat sehingga Januari 2009 (nilai tertinggi $7.47 \pm 1.67 \mathrm{mg} \mathrm{m}^{-3}$ ), selepas itu penurunan perlahan sehingga ke Mei 2009. Hasil kajian menunjukkan semua pengukuran parameter fizikokimia air in-situ ( $\mathrm{DO}$ dan $\mathrm{pH})$ dan ex-situ $\left(\mathrm{NO}_{3}\right.$ dan $\left.\mathrm{PO}_{4}\right)$ adalah berbeza-beza antara bulan. Nilai parameter tertinggi dan terendah ini direkodkan masing-masing pada bulan September 2008 dan Mei 2009. Selepas kejadian pasang-surut merah, nutrien kepekatan $\left(\mathrm{NO}_{3}\right.$ dan $\left.\mathrm{PO}_{4}\right)$, oksigen terlarut dan pH berkurangan berbanding sebelum fenomena ini. Min bandingan antara bulan menunjukkan perbezaan yang signifikan untuk rekod suhu antara bulan kajian ( $p \leq 0.05)$. Suhu terendah dan tertinggi masing-masing direkod pada Februari 2009 dan September 2008, tetapi tiada perbezaan yang bererti untuk kemasinan ( $p \geq 0.05$ ). Kajian ini menunjukkan data satelit SeaWiFS memberikan maklumat berguna tentang variasi spatio-temporal di Teluk Parsi dalam mewujudkan trend umum yang lebih sukar untuk ditentukan melalui pengukuran tanah rutin.

Kata kunci: Kematian ikan; klorofil- $\alpha$; ledakan; SeaWiFS; Teluk Parsi 


\section{INTRODUCTION}

Persian Gulf has countless economic (mainly tanker traffic and fisheries) and recreational activities, with the consequence of being threatened by dramatic dangers and pollution. As an important aquatic ecosystem, Persian Gulf should be studied extensively using remote sensing techniques. Owing to specific characteristics of the region, the mechanisms regulating the variability of remotelysensed chlorophyll- $\alpha$ concentration (CHL) in this Gulf may be significantly different from the processes typical to most parts of the ocean. Among the factors analyzed in this study, wind mixing is an important factor regulating vertical stratification of water column and phytoplankton biomass at seasonal time scale (Longhurst et al. 1995).

An increase in chlorophyll- $\alpha$ concentration indicates eutrophication in aquatic systems, which is associated with low biodiversity and hence deprives the aquatic environment of sufficient ecosystem services. Chlorophyll- $\alpha$ is considered one of the main components that contribute to turbidity in aquatic ecosystems. Turbidity is one of the variables that define the water quality of aquatic ecosystems (Lloyd 1987) and hence dictates the fate of the entire biodiversity, which includes fisheries, mammals and birds. Increase in turbidity can result in a shift from a clear to turbid state, which adversely destabilizes the ecosystem services and functions (Scheffer 1999). Turbidity is therefore detrimental to the local community livelihood that is largely dependent on income from the sale of fish and tourism-related revenue (Namin et al. 2013; Sharifinia et al. 2012). Therefore, restoration of the ecosystem services and functions requires an understanding of the turbidity dynamics in order to arrive at informed management decisions. The understanding of the spatio-temporal dynamics of turbidity requires frequent monitoring of the turbidity characteristics such as chlorophyll- $\alpha$ concentration. However, it is difficult to acquire such data through routine ground measurements because of the high cost and time involved. Remotesensing technology has the potential to present synoptic estimates of chlorophyll- $\alpha$ in Persian Gulf.

This study focused on the analysis of seasonal and interannual variability's of remotely-sensed CHL in the Persian Gulf. CHL measured by Sea viewing Wide Fieldof-view Sensor (SeaWiFS) instruments was analyzed as a proxy of phytoplankton biomass in conjunction with the environmental factors potentially related to phytoplankton growth and distribution. A great deal of prior research has been done on remotely sensed retrieval of chlorophyll- $\alpha$ from satellite images in marine systems using the Seaviewing Wide Field of-view Sensor (SeawiFS) (O'Reilly et al. 2000), Landsat TM (Ekstrand 1992), Medium Resolution Imaging Spectrometer (MERIS) (Gordoa et al. 2008) and Moderate Resolution Imaging Spectroradiometer (MODIS) (Binding et al. 2012; Dall'Olmo et al. 2005; Gitelson et al. 2009; Ndungu et al. 2013).

In this study, we investigate the use of SeawiFs data in the retrieval of chlorophyll- $\alpha$ as a measure of the phytoplankton biomass in Persian Gulf. This is because the imagery is readily available free of charge and has daily temporal resolution allowing frequent monitoring of water quality. This is useful especially for water quality studies in developing countries like Iran, where continuous data collection is a challenge due to limitations in allocating funds for research and monitoring projects. In addition, successful retrieval of satellite data is fundamental because it allows retrospective analysis of the chlorophyll- $\alpha$ in aquatic system and therefore provides data at times when ground measurements do not exist.

Different efforts have been made to consider the possibility of using chlorophyll products of ocean color sensors in order to detect affected regions by kinds of blooms in different parts of the world (Stumpf et al. 2003). Other different methods for detection of special kinds of algal blooms based on their unique optical features have been developed (Cannizzaro \& Carder 2006). There have also been studies based on the use of classification techniques in order to separate regions infected by algal blooms from other waters with distinct optical features. The red tide seen in Persian Gulf in the years 2008 and 2009 is originated from a phytoplankton Cochlodinium polykrikoides (Richlen et al. 2010). Red tide phenomenon have occurred in Persian Gulf (20082009) studied in this work.

The objectives of the study were evaluation of monthly spatial variations of chlorophyll- $\alpha$ concentration in Persian Gulf using SeaWiFS data and determination of physic-chemical factors influencing on variability of chlorophyll- $\alpha$.

\section{MATERIAL AND METHODS}

\section{STUDY AREA}

The Persian Gulf, located in the southwest of the Asian continent is a shallow, semi-enclosed basin in a typical rid zone and is an arm of the Indian Ocean. It is located between the longitudes of $48-57^{\circ} \mathrm{E}$ and the latitude of $24-30^{\circ} \mathrm{N}$ (Figure 1). This Gulf is connected to the deep Gulf of Oman through the narrow Strait of Hormuz. The Persian Gulf covers an area of approximately 226,000 $\mathrm{km}^{2}$ with a length of $990 \mathrm{~km}$. Its width varies from 56 to $338 \mathrm{~km}$, separating Iran from the Arabian Peninsula where the shortest distance is about $56 \mathrm{~km}$ in the Strait of Hormuz. This basin has an average depth of about 35 $\mathrm{m}$ and the deepest water depth is approximately $107 \mathrm{~m}$ (Emery 1956; Purser \& Seibold 1973).

The formation of hyper saline water leads to inverse estuarine circulation with the highly saline waters concentrating in the bottom layer, leaving the Gulf through the deep part of the Strait of Hormuz and the Gulf of Oman and spreading at the depth 200-300 m throughout the Arabian Sea (Banse 1997; Prasad et al. 2001). Evaporated water is replaced by a surface inflow 
of lower salinity ( $-36.5 \mathrm{psu})$ from the Gulf of Oman. This inflow penetrates into the Gulf and is carried northwards along the Iranian coast, gradually increasing in salinity to more than 40 psu (Michael Reynolds 1993). The inflow is seasonal, with maximum in late spring (Swift \& Bower 2003), when it spreads as far as the north-western part of the Gulf.

The main freshwater supply of the Gulf comes from the Tigris, Euphrates and Karoun Rivers, which all discharge into the Shatt Al-Arab waterway in Kuwaiti and Iraqi coast. The estimates of river discharge volume vary between 36 and $110 \mathrm{~km}^{3} \mathrm{yr}^{-1}$, i.e. 0.15-0.46 $\mathrm{m} \mathrm{yr}^{-1}$ averaged over the entire Gulf area (Michael Reynolds 1993). Maximum freshwater discharge occurs in late springearly summer. Precipitation over the Gulf area is also very low (0.07-0.1 $\mathrm{m} \mathrm{yr}^{-1}$ ) (Marcella \& Eltahir 2008); the total freshwater input is less than the evaporation rate by a factor of 5-10. The Shatt Al-Arab discharge is expected to amplify the Saudi-Emirate coastal current (Michael Reynolds 1993); its influence is especially evident along the south-western Gulf coast from Iraq to Qatar. Deep part of the Gulf is characterized by pronounced haline stratification (Michael Reynolds 1993; Swift \& Bower 2003). In contrast, water column in the shallow $(<10-15$ $\mathrm{m})$ northern, western and southern Gulf is well mixed as a result of wind stress and tidal turbulence (John 1992).

Persistent north-westerly winds produce southeastward coastal currents and resulting up welling along the North-eastern (Iranian) and down welling along the South-western (Saudi) coasts (Michael Reynolds 1993). Winds are most intensive in spring-summer when the intense 'Shamal' events propagate from the northwest to the central and southern Gulf. During autumn the winds are weaker and less variable. Intense temperature differences between land and water result in strong breeze winds, which in turn stimulate intensive mixing processes in coastal regions (Nezlin et al. 2010).

\section{PHYSICOCHEMICAL PARAMETERS DETERMINATION}

For determinations of nutrient concentrations, water samples were collected in polyethylene bottles, fixed with $\mathrm{HgCl}_{2}$ and immediately refrigerated until further processing. Meanwhile, on each sampling site, some water measurements including $\mathrm{pH}$ and dissolved oxygen were also measured by Hack multi- analyzer model 156. Phosphate was measured by Vanadomolybdo phosphoric Acid colorimetric method. Nitrite was also measured by spectrophotometer UV/visible (Varian-carry 100) according to Manual of Oceanographic Observations and Pollutant Analysis Methods procedures (Marine environment assessment marine meteorology, 1999).

\section{SATELLITE IMAGERIES}

In the absence of direct observations of sea features, satellite data can be one of the best ways for investigation of sea surface properties. The reflectance from sea interface can be related to the concentration of a physic-chemical constituent of sea. Phytoplankton effects on optical properties of water and ocean color can be different in various amount of phytoplankton then remote sensing can be used to determine the various water constituents, e.g. chlorophyll- $\alpha$.

In this study, data products of chlorophyll-a concentration (CHL, mg m-3) in the surface layer of the Persian Gulf region have been obtained from SeaWiFs (Sea-Viewing Wide Field-of-View Sensor) dataset. This data comprises of monthly mean sea surface chlorophyll$\alpha$ maps at $9 \mathrm{~km}$ resolution. The data set downloaded from http://www.myocean.eu. In this data, for extraction of

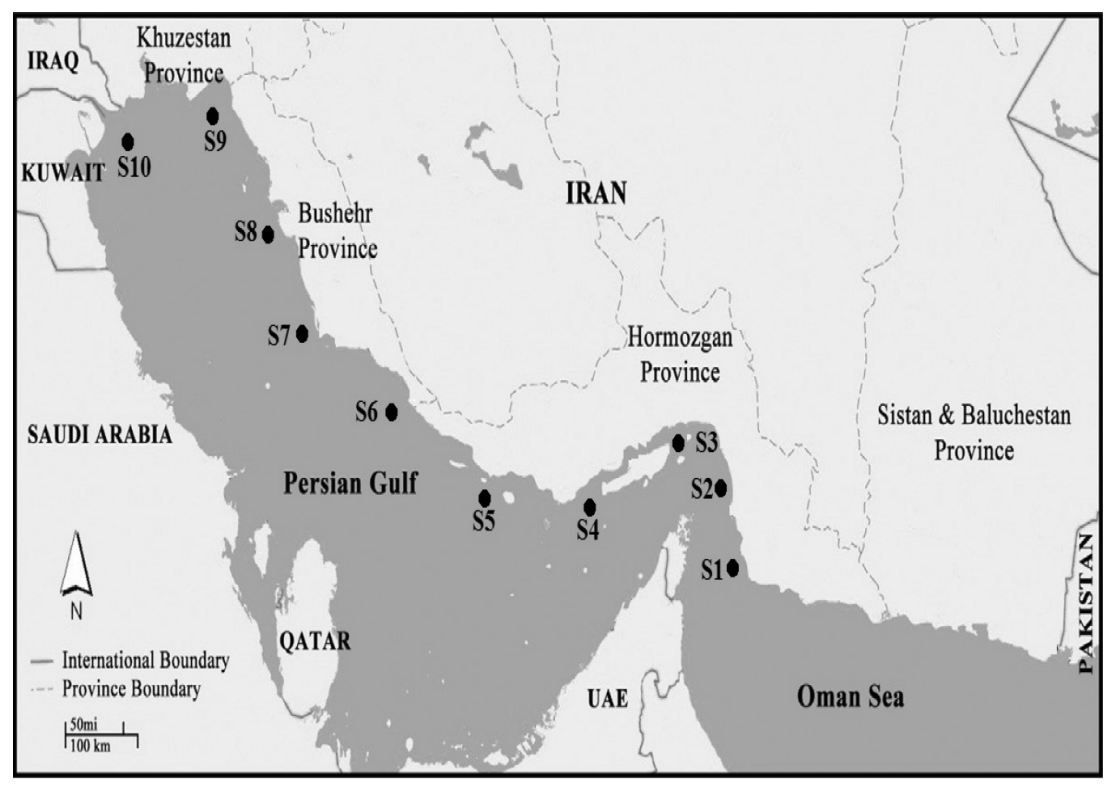

FIGURE 1. Study area of Persian Gulf (S: Station) 
chlorophyll from SeaWiFS used version 4 of algorithm for reprocessing of SeaWiFS data (O'Reilly et al. 2000). This algorithm better represents oligotrophic and eutrophic waters (O'Reilly et al. 2000).

The temperature and salinity data that were used in this study are monthly combined products from satellite and insitu that downloaded from http://www.myocean.eu. In this data, first, sea level anomalies and sea surface temperature satellite observations are projected onto the vertical via a multiple linear regression method and using covariance deduced from historical observations that this leads to synthetic fields. Then the synthetic fields and in-situ T/S profiles are combined through an optimal interpolation method. This leads to the Armor3D T/S combined fields. For more information about temperature and salinity data refer to (Guinehut et al. 2012; Larnicol et al. 2006; Mulet et al. 2012).

\section{FISHING CATCH DATA}

The catch data in this study are based on Fisheries Statistical Yearbook of Iran (Fisheries Statistical Yearbook 2009).
RESULTS

\section{CHLOROPHYLL- $\alpha$ CONCENTRATION}

Variability of Chlorophyll- $\alpha$ plot from September 2008 to May 2009 in Persian Gulf showed that September 2008 had lowest value $\left(1.57 \pm 0.14 \mathrm{mg} \mathrm{m}^{-3}\right)$ than other years except May 2009, then tended to increase up to January 2009 (Highest value: $7.47 \pm 1.67$ ), then a slow decrease up to May 2009. The considerable points of peaks are occurring in December 2008, January and February 2009 (Figure 2). Seasonal CHL- $\alpha$ cycle in the open Gulf waters was characterized by winter maximum and summer minimum, which is typical to subtropical ocean (Longhurst 1995).

Figure 3 shows the distribution of annual chlorophyll- $\alpha$ concentration in the range of $1.7-11.2 \mathrm{mg} \mathrm{m}^{-3}$ during September 2008 to May 2009 in nine stations. Higher concentrations are evidently seen along the Hormozgan province (S3 and S4) and decreases award to Bushehr and Khuzestan provinces. Minimal concentration of Chl- $\alpha$ $\left(1.7 \pm 0.15 \mathrm{mg} \mathrm{m}^{-3}\right)$ and maximal $\left(11.2 \pm 1.5 \mathrm{mg} \mathrm{m}^{-3}\right)$ recorded in S8 and S3 stations, respectively.

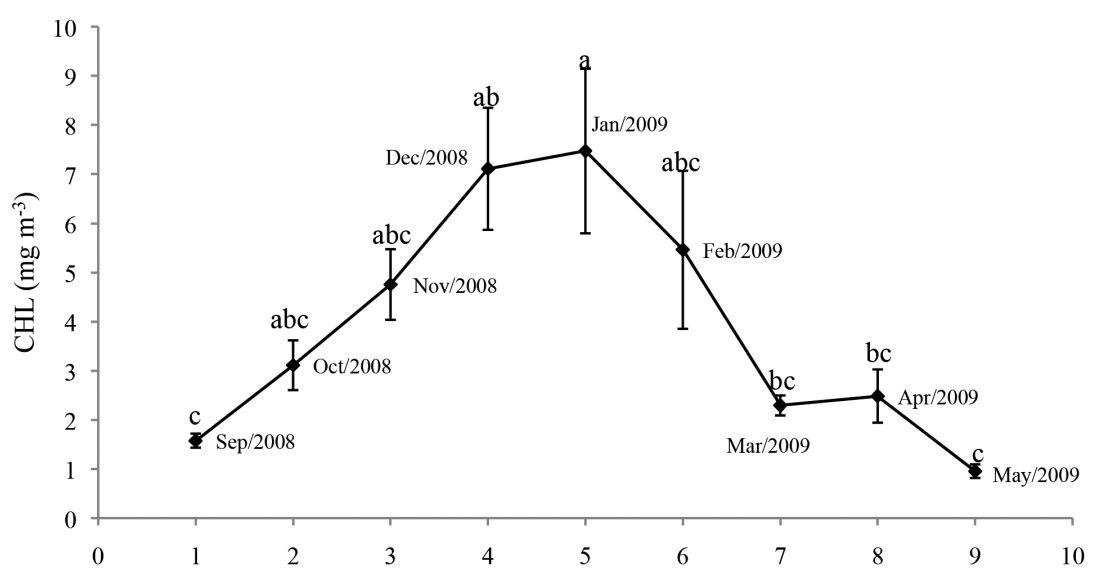

FIGURE 2. Monthly chlorophyll- $\alpha$ concentration (Mean \pm SE) of the Persian Gulf from September 2008 to May 2009

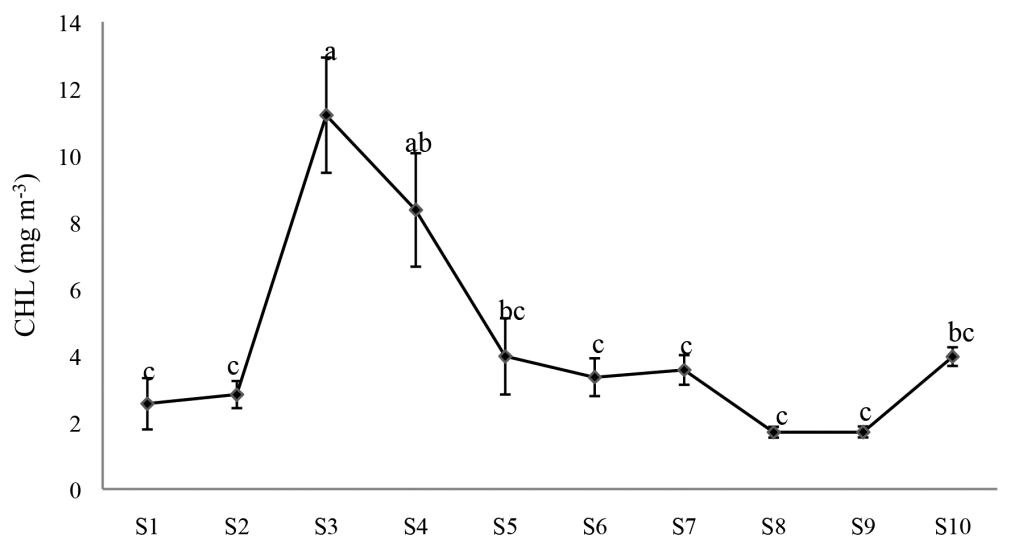

FIGURE 3. Mean chlorophyll- $\alpha$ concentration (Mean \pm SE) of the Persian Gulf from September 2008 to May 2009 for each station 


\section{PHYSICOCHEMICAL PARAMETERS}

The present study focuses on the temperature, dissolved oxygen, salinity, $\mathrm{pH}$ and nutrient concentrations in the Persian Gulf during the red tide phenomenon. Physical and chemical factors fluctuated before and after the occurrence of the red tide. Mean values $( \pm \mathrm{SD})$ of water physicochemical parameters in each sampling site, for the whole sampling period, are presented in Table 1. Temperature range was 20.24-31.91 ${ }^{\circ} \mathrm{C}$, salinity $38.26-38.98$ ppt and nutrient concentration ranges were $0.106-0.378 \mathrm{mg} \mathrm{l}^{-1}$ nitrate and 0.051-0.565 $\mathrm{mg} \mathrm{l}^{-1}$ phosphate, respectively.

The result showed that all water physicochemical parameters measurement in-situ (DO and $\mathrm{pH}$ ) and ex-situ $\left(\mathrm{NO}_{3}\right.$ and $\left.\mathrm{PO}_{4}\right)$, were varied among the different month. The highest and lowest values of these parameters were recorded in September 2008 and May 2009, respectively. After occurrence of red tide, nutrient concentration $\left(\mathrm{NO}_{3}\right.$ and $\mathrm{PO}_{4}$ ), dissolved oxygen and $\mathrm{pH}$ were reduce rather than before this phenomenon (Figures 4 and 5).

The results compare means between various months revealed significant differences for temperature records among the months of study. The lowest and highest of temperature recorded in February 2009 and September 2008, respectively, but no significant differences were found in salinity (Figures 6 and 7).

\section{MONTHLY AVERAGE OF CHLOROPHYLL- $\alpha$ CONCENTRATION MAPS}

Monthly patterns of chlorophyll- $\alpha$ concentration in the Persian Gulf, derived from the composite average of respective monthly images between September 2008 and May 2009, are presented in Figure 8. As indicated in this figure, concentration of chlorophyll- $\alpha$ increased in October 2008 in the Strait of Hormuz and spread to the Gulf along the Iranian coast. Very intensive bloom started in October 2008 when intense fish mortality was observed in the Iranian coastal waters.

\section{FISHERIES CATCH RATE IN IRANIAN WATERS}

Small pelagic fish catches declined sharply after the red tide, while the amount of shrimp catches (Large shrimp:

TABLE 1. Monthly average of physical and chemical parameters at different stations (September 2008-May 2009)

\begin{tabular}{ccccccc}
\hline $\begin{array}{c}\text { Month / } \\
\text { Parameters }\end{array}$ & *Salinity $(\mathrm{ppt})$ & $\begin{array}{c}* \text { Temperature } \\
\left({ }^{\circ} \mathrm{C}\right)\end{array}$ & $* * \mathrm{pH}$ & $* * \mathrm{DO}\left(\mathrm{mg} \mathrm{l}^{-1}\right)$ & $* * \mathrm{NO} 3\left(\mathrm{mg} \mathrm{l}^{-1}\right)$ & $* * \mathrm{PO} 4\left(\mathrm{mg} \mathrm{l}^{-1}\right)$ \\
\hline Sep-08 & $38.75 \pm 0.75$ & $31.91 \pm 0.7$ & $8.65 \pm 0.12$ & $8.84 \pm 0.11$ & $0.378 \pm 0.007$ & $0.565 \pm 0.02$ \\
Oct-08 & $39.26 \pm 1.09$ & $29.75 \pm 0.96$ & $8.52 \pm 0.1$ & $8.77 \pm 0.1$ & $0.377 \pm 0.008$ & $0.561 \pm 0.02$ \\
Nov-08 & $38.76 \pm 1.18$ & $26.59 \pm 1.3$ & $8.67 \pm 0.11$ & $7.98 \pm 0.28$ & $0.196 \pm 0.03$ & $0.353 \pm 0.008$ \\
Dec-08 & $38.98 \pm 1.55$ & $23.38 \pm 1.9$ & $8.45 \pm 0.08$ & $7.06 \pm 0.35$ & $0.158 \pm 0.01$ & $0.275 \pm 0.03$ \\
Jan-08 & $38.7 \pm 1.45$ & $20.76 \pm 2.4$ & $8.35 \pm 0.12$ & $7.02 \pm 0.33$ & $0.168 \pm 0.02$ & $0.327 \pm 0.05$ \\
Feb-09 & $38.71 \pm 1.34$ & $20.24 \pm 2.2$ & $8.42 \pm 0.1$ & $6.46 \pm 0.45$ & $0.167 \pm 0.01$ & $0.155 \pm 0.05$ \\
Mar-09 & $38.83 \pm 1.57$ & $21.04 \pm 2.1$ & $8.38 \pm 0.12$ & $5.2 \pm 0.42$ & $0.147 \pm 0.01$ & $0.059 \pm 0.03$ \\
Apr-09 & $38.3 \pm 1.45$ & $23.57 \pm 1.7$ & $8.31 \pm 0.13$ & $4.67 \pm 0.75$ & $0.142 \pm 0.01$ & $0.051 \pm 0.03$ \\
May-09 & $38.26 \pm 1.09$ & $27.53 \pm 1.2$ & $8.23 \pm 0.15$ & $4.37 \pm 0.51$ & $0.106 \pm 0.03$ & $0.058 \pm 0.03$ \\
\hline
\end{tabular}

*SeaWiFS data

***Measured data

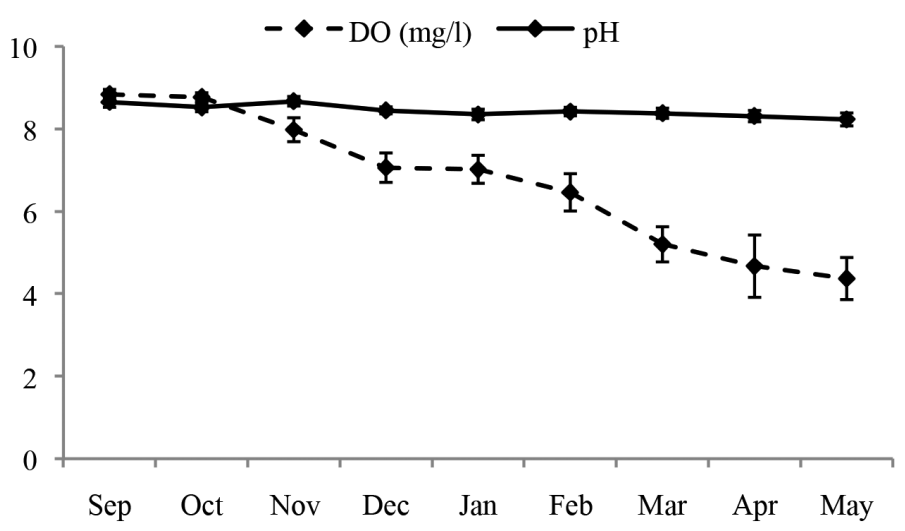

FIGURE 4. Monthly Dissolve oxygen and $\mathrm{pH}($ Mean $\pm \mathrm{SD})$ of the Persian Gulf from September 2008 to May 2009 


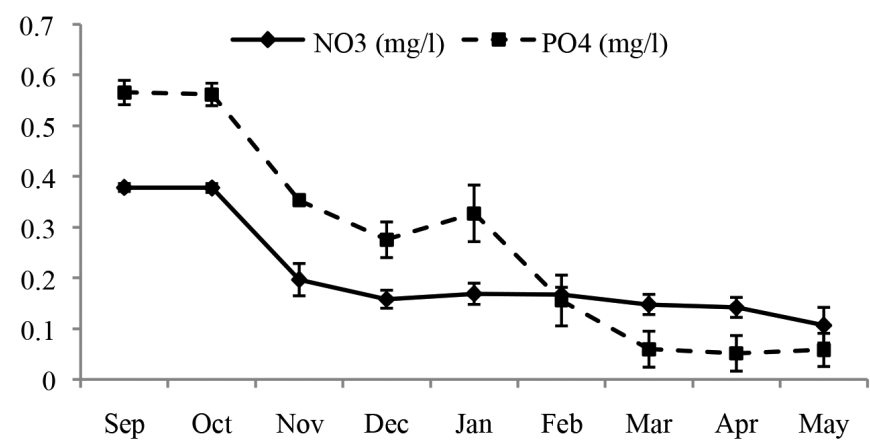

FIGURE 5. Monthly $\mathrm{NO}_{3}$ and $\mathrm{PO}_{4}($ Mean $\pm \mathrm{SD}$ ) concentration of the Persian Gulf from September 2008 to May 2009

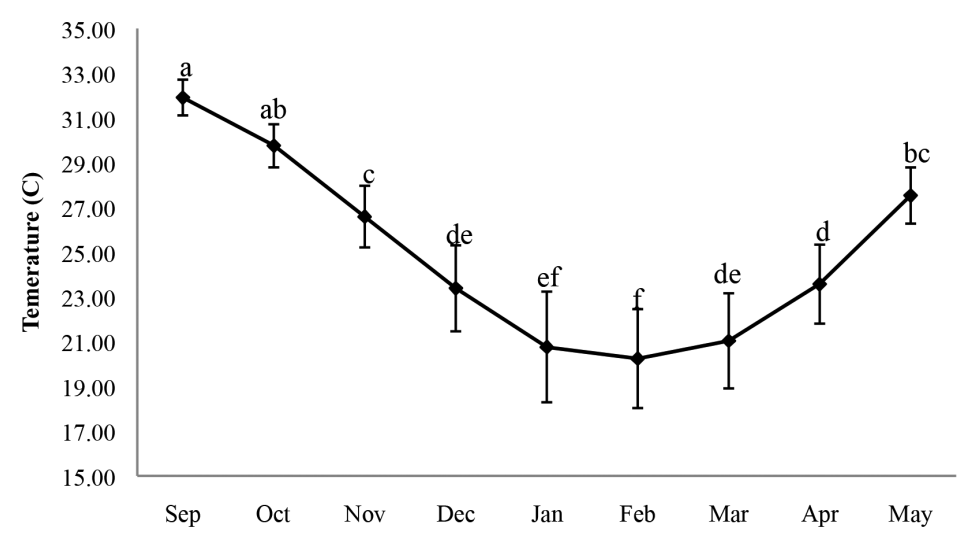

FIGURE 6. Monthly temperature (Mean \pm SD) concentration of the Persian Gulf from September 2008 to May 2009

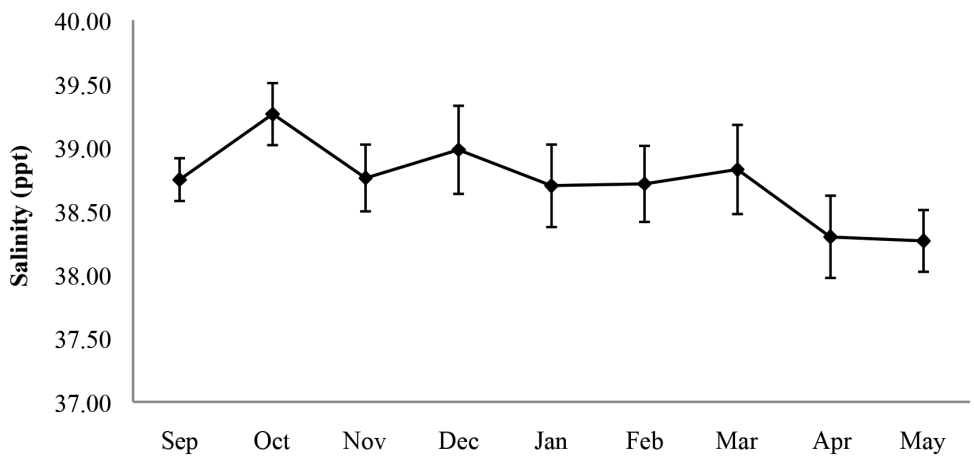

FIGURE 7. Monthly salinity (Mean \pm SD) concentration of the Persian Gulf from September 2008 to May 2009

94.4\% and small shrimp: $3.6 \%$ ) and large pelagic fish rose rather than before the red tide (Figures 9 and 10).

\section{DISCUSSION}

\section{VARIATION IN CHLOROPHYLL- $\alpha$ CONCENTRATION BEFORE} AND AFTER RED TIDE PHENOMENON

Historical reports on the occurrence and frequency of Harmful Algal Blooms (HABs) in the Persian Gulf are scarce; however, several taxa of potentially toxic phytoplankton have been documented in the Persian Gulf and nearby coastal waters, as have red tides resulting in significant fish kills and aquaculture losses. In a review of phytoplankton ecology in the Persian Gulf, Rao and Al-Yamani (1998) explain a north to south gradient in phytoplankton species diversity, characterizing the northern gulf as an area of low diversity, dominated by diatoms and the open Persian Gulf as an area of high phytoplankton biodiversity, comprising primarily tropical species. Red tide resulting from this 


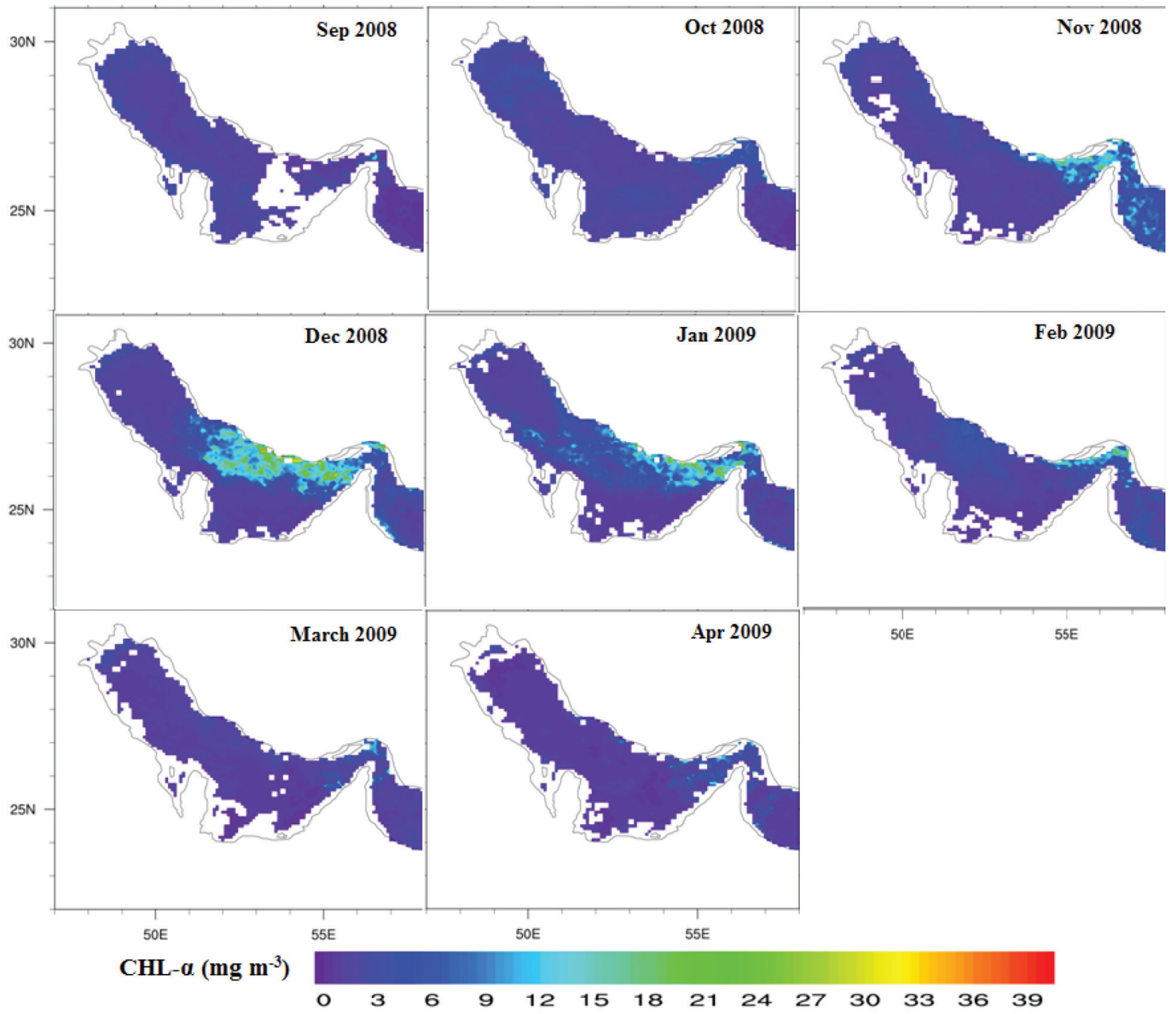

FIGURE 8 . Monthly patterns of chlorophyll- $\alpha$ concentration in the Persian Gulf

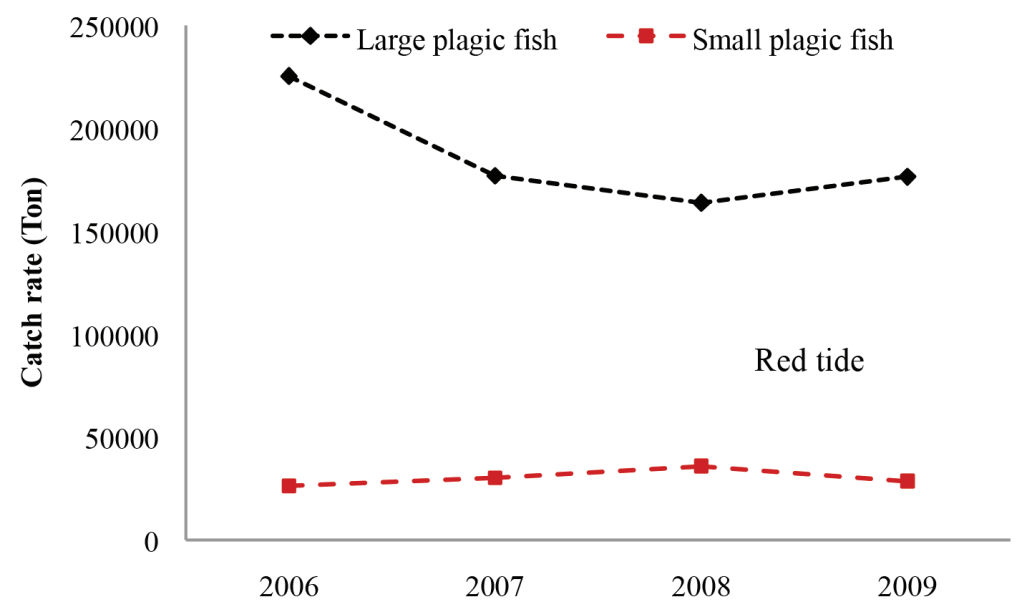

FIGURE 9. Annual catch rate of small and large pelagic fish before and after red tide in Persian Gulf 
species has been extended worldwide (Fatemi et al. 2012) mainly in warm temperate and tropical waters (Tester \& Steidinger 1997) from which and Persian Gulf has not been an exception. According to result of this study, peaks of red tide phenomenon are occurring in December 2008, January and February 2009 (Figures 2 and 8). The bloom started from Hormozgan province (S1, S2 and S3) in the Strait of Hormuz in October 2008 and then extended westward to the inner Persian Gulf within a few months. It covered most of the area mainly inshore and partly offshore. In the south it had the same trend and started from Omani coasts and then to UAE. The first efforts to identify the cause of this unusual bloom which turned the color of water into a stinky dark red blanket showed that this had been caused by Cochlodinium polykrikoides (Gymnodiniaceae) which was a new species to appear and to bloom in the area (Matsuoka et al. 2010). Using molecular phylogenetic technique, Matsuoka et al. (2010) also found that the origin of this species belong to the American/Malaysian ribo-type which is distributed worldwide.

Red tide phenomenon started at autumn (October 2008) and lasted for the winter and spring seasons while the usual blooms for this area which is usually occurs in autumn and spring but never occurred during the cold periods (Fatemi et al. 2012). Usual blooms last for only a few days or weeks while this bloom lasted for about 7 months in the area continuously (Fatemi et al. 2012).

\section{RELATIONSHIP BETWEEN PHYSICOCHEMICAL PARAMETERS AND ALGAL BLOOM}

In the Persian Gulf the seawater temperature varies significantly between different months (Figure 6). Many investigators have noted the global expansion of HABs during the past several decades with regard to their impacts (Glibert et al.2005). According to result of this study algal bloom in Persian Gulf (owing to C.polykrikoides), occurs in temperature range from 29.75 \pm 0.96 (October 2008: beginning to bloom) to $20.24 \pm 2.2$ (in February 2009) and peak of bloom was observed in January 2009 at a temperature of $20.76 \pm 2.4$. In this study salinity range was 38.26-38.98 ppt. There is clear overlap in the temperature and salinity ranges for the reported $C$. polykrikoides blooms. The data generally support the description of this organism as eurythermal and euryhaline, well adapted to warm $\left(>20^{\circ} \mathrm{C}\right)$ moderate (30-33) salinities often associated with offshore, possibly tropical or subtropical waters (Kim et al. 2004; Kudela \& Gobler 2012; Nagai et al. 2009). However, some blooms, particularly in North America, have been associated with the intrusion of cool water masses and more brackish salinities (Gobler et al. 2008; Morse et al. 2011; Mulholland et al. 2009; Tomas \& Smayda 2008). Thus based on previous studies, $C$. polykrikoides exhibits a wide range of temperatures over which it can survive in a vegetative state, despite a relatively narrow 'optimal' temperature and salinity preference (Kudela \& Gobler 2012; Trainer et al. 2010). Based on results of this study, algal bloom in Persian Gulf caused C.polykrikoides to exhibits a reasonably high temperature and salinity optimum $\left(>20^{\circ} \mathrm{C}, 38 \mathrm{ppt}\right)$.

According to results of this study, salinity shows no significant monthly variation (Figure 7). Ranges of salinity in the Persian Gulf fluctuated between 38.26 \pm 0.24 (in May 2009) and 39.26 \pm 0.24 (October 2008), which this ranges suitable for growth of cause of this bloom (C.polykrikoides) in Persian Gulf. These results were corroborated by data from Kim et al. (2004), who examined the salinity tolerance for a Japanese strain of $C$. polykrikoides in culture. Optimal conditions were again identified a salinity of 34 , which resulted in maximal growth. Iwataki et al. (2008) and Gobler et al. (2008) have similarly documented the growth characteristics of multiple $C$. polykrikoides strains. The growth response to salinity was approximately similar, with salinity optima of 32-34.4. Maximal growth in this study was considerably higher than previously reported.

In September 2008, before bloom became dominant, both $\mathrm{NO}_{3}$ and $\mathrm{PO}_{4}$ concentrations in the Persian Gulf was higher than time of occurrence bloom and gradually reduced their rates during bloom. Consistent with these

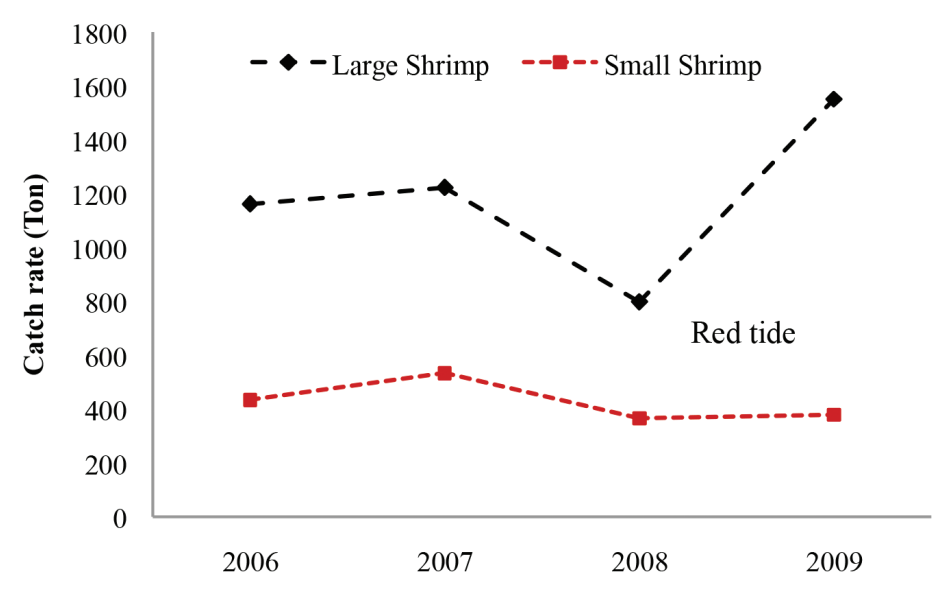

FIGURE 10. Annual catch rate of small and large shrimp before and after red tide in Persian Gulf 
results, $\mathrm{NO}_{3}$ and $\mathrm{PO}_{4}$ concentrations have been major role in increasing growth rates and photosynthesis of Cochlodinium during bloom in Persian Gulf, which was consistent with the results of other studies (Gobler et al. 2008; Lee \& Lee 2006; Morse et al. 2011; Mulholland et al. 2009). There are several examples worldwide of increases in HABs linked to increased nutrient loading. Increasing linkages between nutrient loading and coastal marine HABs have more recently been recognized (Glibert \& Burkholder 2006; Glibert et al. 2005).

Algal blooms have dramatic effects on water chemistry, most notably $\mathrm{pH}$ and DO. In this study, the highest and lowest values of $\mathrm{pH}$ and $\mathrm{DO}$ were recorded in September 2008 and May 2009, respectively. After occurrence red tide nutrients, $\mathrm{DO}$ and $\mathrm{pH}$ reduce rather than before this phenomenon (Figures 4 and 5). Algal blooms during respiration remove the dissolved oxygen (DO) from the water column which may lead to little or no oxygen in the water column. These conditions can also be created when a large quantity of algae die and decompose (Kuwae et al. 2006).

\section{EFFECTS OF ALGAL BLOOM ON FISHERIES CATCH RATE IN IRANIAN WATERS}

The results shown in Figures 9 and 10 demonstrate that red tide is one main cause of mortality rate in small pelagic fish and increase catch rate small and large benthic shrimp after occurrence this phenomenon. Many factors can affect on abundance of fishes, so it can be difficult to identify the specific cause of a decline in fish abundance from observational field studies. However, the fact that nearly every species in all habitats showed the same pattern of changes in abundance (with the exception of clupeids) suggests a large-scale environmental perturbation was the underlying cause. Red tide phenomena corresponded with massive fish kills, decreases in fish abundance and diversity, and changes in community structure (Gannon et al. 2009). In the present study, distinct differences were found between red tide and non-red tide periods regarding the structures of the fish communities (Figures 9 and 10). Thus, the data were consistent with regarding the effects of red tides on fish abundance.

\section{CONCLUSION}

An extensive red tide phenomenon that occurred in 2008 in the Persian Gulf was studied. Satellite imagery from SeaWiFs, was used to track the outbreak and evolution of the red tide phenomenon. This study indicated that variability of remotely-sensed chlorophyll- $\alpha$ in the Persian Gulf can be explained by SeaWiFs images. This is because, in such waters, the signal upwelling in the spectral regions carries precious information about the phytoplankton absorption and total backscattering coefficients. Our findings imply that the existing data archive of SeaWiFs images could be used to study quantitatively the dynamics of open Gulf waters.

\section{ACKNOWLEDGMENTS}

We greatly thank the post graduate students who have helped us on this work: Ali Reza Nafarzadegan, Moslem Daliri and Amirali Moradinasab.

\section{REFERENCES}

Banse, K. 1997. Irregular flow of Persian (Arabian) Gulf water to the Arabian sea. Journal of Marine Research 55: 1049-1067.

Binding, C., Greenberg, T. \& Bukata, R. 2012. An analysis of MODIS-derived algal and mineral turbidity in Lake Erie. Journal of Great Lakes Research 38: 107-116.

Cannizzaro, J.P. \& Carder, K.L. 2006. Estimating chlorophyll- $\alpha$ concentrations from remote-sensing reflectance in optically shallow waters. Remote Sensing of Environment 101: 13-24.

Dall’Olmo, G., Gitelson, A.A., Rundquist, D.C., Leavitt, B., Barrow, T. \& Holz, J.C. 2005. Assessing the potential of SeaWiFS and MODIS for estimating chlorophyll concentration in turbid productive waters using red and nearinfrared bands. Remote Sensing of Environment 96: 176-187.

Ekstrand, S. 1992. Landsat TM based quantification of chlorophyll- $\alpha$ during algae blooms in coastal waters. International Journal of Remote Sensing 13: 1913-1926.

Emery, K.O. 1956. Sediments and water of Persian Gulf. AAPG Bulletin 40: 2354-2383.

Fatemi, S., Nabavi, S., Vosoghi, G., Fallahi, M. \& Mohammadi, M. 2012. The relation between environmental parameters of Hormuzgan coastline in Persian Gulf and occurrence of the first harmful algal bloom of Cochlodinium polykrikoides (Gymnodiniaceae). Iranian Journal of Fisheries Sciences 11: 475-489.

Fisheries Statistical Yearbook, I.W. 2009. Fisheries Administration, Council of Agriculture, Executive Tehran. 113.

Gannon, D.P., McCabe, E.B., Camilleri, S.A., Gannon, J.G., Brueggen, M.K., Barleycorn,A.A.,Palubok, V.I., Kirkpatrick, G.J. \& Wells, R.S. 2009. Effects of Karenia brevis harmful algal blooms on nearshore fish communities in southwest Florida. Mar. Ecol. Prog. Ser. 378: 171-186.

Gitelson, A.A., Gurlin, D., Moses, W.J. \& Barrow, T. 2009. A bio-optical algorithm for the remote estimation of the chlorophyll-a concentration in case 2 waters. Environmental Research Letters 4: 045003.

Glibert, P. \& Burkholder, J. 2006. The complex relationships between increases in fertilization of the earth, coastal eutrophication and proliferation of harmful algal blooms. Ecology of Harmful Algae 189: 341-354.

Glibert, P.M.,Anderson, D.M., Gentien, P., Graneli,E. \& Sellner, K.G. 2005. The global, complex phenomena of harmful algal blooms. Oceanography 18(2): 136-147.

Gobler, C.J., Berry, D.L., Anderson, O.R., Burson, A., Koch, F., Rodgers, B.S., Moore, L.K., Goleski, J.A., Allam, B. \& Bowser, P. 2008. Characterization, dynamics, and ecological impacts of harmful Cochlodinium polykrikoides blooms on eastern Long Island, NY, USA. Harmful Algae 7: 293-307.

Gordoa, A., Illas, X., Cruzado, A. \& Velásques, Z. 2008. Spatiotemporal patterns in the north-western Mediterranean from MERIS derived chlorophyll- $\alpha$ concentration. Scientia Marina 72: 757-767.

Guinehut, S., Dhomps, A.L., Larnicol, G. \& Le Traon, P.Y. 2012 High resolution 3-D temperature and salinity fields derived from in-situ and satellite observations. Ocean Science 8: 845-857. 
Iwataki, M., Kawami, H., Mizushima, K., Mikulski, C.M., Doucette, G.J., Relox Jr, J.R., Anton, A., Fukuyo, Y. \& Matsuoka, K. 2008. Phylogenetic relationships in the harmful dinoflagellate Cochlodinium polykrikoides (Gymnodiniales, Dinophyceae) inferred from LSU rDNA sequences. Harmful Algae 7: 271-277.

John, V.C. 1992. Harmonic tidal current constituents of the western Arabian Gulf from moored current measurements. Coastal Engineering 17: 145-151.

Kim, D.I., Matsuyama, Y., Nagasoe, S., Yamaguchi, M., Yoon, Y.H., Oshima, Y., Imada, N. \& Honjo, T. 2004. Effects of temperature, salinity and irradiance on the growth of the harmful red tide dinoflagellate Cochlodinium polykrikoides Margalef (Dinophyceae). Journal of Plankton Research 26: 61-66.

Kudela, R.M. \& Gobler, C.J. 2012. Harmful dinoflagellate blooms caused by Cochlodinium sp.: Global expansion and ecological strategies facilitating bloom formation. Harmful Algae 14: 71-86.

Kuwae, T., Kamio, K., Inoue, T., Miyoshi, E. \& Uchiyama, Y. 2006. Oxygen exchange flux between sediment and water in an intertidal sandflat, measured in-situ by the eddy-correlation method. Marine Ecology Progress Series 307: 59-68.

Larnicol, G., Guinehut, S., Rio, M., Drevillon, M., Faugere, Y. \& Nicolas, G. 2006. The Global Observed Ocean Products of the French Mercator Project. https://earth.esa.int.

Lee, Y.S. \& Lee, S.Y. 2006. Factors affecting outbreaks of Cochlodinium polykrikoides blooms in coastal areas of Korea. Marine Pollution Bulletin 52: 626-634.

Lloyd, D.S. 1987. Turbidity as a water quality standard for salmonid habitats in Alaska. North American Journal of Fisheries Management 7: 34-45.

Longhurst, A., Sathyendranath, S., Platt, T. \& Caverhill, C. 1995. An estimate of global primary production in the ocean from satellite radiometer data. Journal of Plankton Research 17: 1245-1271.

Marcella, M.P. \& Eltahir, E.A. 2008. The hydroclimatology of Kuwait: Explaining the variability of rainfall at seasonal and interannual time scales. Journal of Hydrometeorology 9(5): .

Matsuoka, K., Mizuno, A., Iwataki, M., Takano, Y., Yamatogi, T., Yoon, Y.H. \& Lee, J.B. 2010. Seed populations of a harmful unarmored dinoflagellate Cochlodinium polykrikoides Margalef in the East China Sea. Harmful Algae 9: 548-556.

Michael Reynolds, R. 1993. Physical oceanography of the Gulf, Strait of Hormuz, and the Gulf of Oman-Results from the Mt Mitchell expedition. Marine Pollution Bulletin 27: 35-59.

Morse, R.E., Shen, J., Blanco-Garcia, J.L., Hunley, W.S., Fentress, S., Wiggins, M. \& Mulholland, M.R. 2011. Environmental and physical controls on the formation and transport of blooms of the dinoflagellate Cochlodinium polykrikoides Margalef in the lower Chesapeake Bay and its tributaries. Estuaries and Coasts 34: 1006-1025.

Mulet, S., Rio, M.H., Mignot, A., Guinehut, S. \& Morrow, R. 2012. A new estimate of the global 3D geostrophic ocean circulation based on satellite data and in-situ measurements. Deep Sea Research Part II: Topical Studies in Oceanography 77: 70-81.

Mulholland, M.R., Morse, R.E., Boneillo, G.E., Bernhardt, P.W., Filippino, K.C., Procise, L.A., Blanco-Garcia, J.L., Marshall, H.G., Egerton, T.A. \& Hunley, W.S. 2009. Understanding causes and impacts of the dinoflagellate, Cochlodinium polykrikoides, blooms in the Chesapeake Bay. Estuaries and Coasts 32: 734-747.
Nagai, S., Nishitani, G., Takano, Y., Yoshida, M. \& Takayama, H. 2009. Encystment and excystment under laboratory conditions of the nontoxic dinoflagellate Alexandrium fraterculus (Dinophyceae) isolated from the Seto Inland Sea, Japan. Phycologia 48: 177-185.

Namin, J.I., Sharifinia, M. \& Makrani,A.B. 2013.Assessment of fish farm effluents on macroinvertebrates based on biological indices in Tajan River (north Iran). Caspian J. Env. Sci. 11: 29-39.

Ndungu, J., Monger, B.C., Augustijn, D.C., Hulscher, S.J., Kitaka, N. \& Mathooko, J.M. 2013. Evaluation of spatio-temporal variations in chlorophyll- $\alpha$ in Lake Naivasha, Kenya: remotesensing approach. International Journal of Remote Sensing 34: 8142-8155.

Nezlin, N.P., Polikarpov, I.G.,Al-Yamani, F.Y., Subba Rao, D. \& Ignatov, A.M. 2010. Satellite monitoring of climatic factors regulating phytoplankton variability in the Arabian (Persian) Gulf. Journal of Marine Systems 82: 47-60.

O’Reilly, J.E., Maritorena, S., Siegel, D.A., O’Brien, M.C., Toole, D., Mitchell, B.G., Kahru, M., Chavez, F.P., Strutton, P. \& Cota, G.F. 2000. Ocean color chlorophyll- $\alpha$ algorithms for SeaWiFS, OC2, and OC4: Version 4. SeaWiFS Postlaunch Calibration and Validation Analyses, Part 3: 9-23.

Prasad, T., Ikeda, M. \& Kumar, S.P. 2001. Seasonal spreading of the Persian Gulf Water mass in the Arabian Sea. Journal of Geophysical Research: Oceans (1978-2012) 106: 1705917071.

Purser, B. \& Seibold, E. 1973. The principal environmental factors influencing Holocene sedimentation and diagenesis in the Persian Gulf. The Persian Gulf pp. 1-9. Springer.

Rao, S. \& Al-Yamani, F. 1998. Phytoplankton ecology in the waters between Shatt Al-Arab and Straits of Hormuz, Arabian Gulf: A review. Plankton Biology and Ecology 45: 101-116.

Richlen, M.L., Morton, S.L., Jamali, E.A., Rajan, A. \& Anderson, D.M. 2010. The catastrophic 2008-2009 red tide in the Arabian gulf region, with observations on the identification and phylogeny of the fish-killing dinoflagellate Cochlodinium polykrikoides. Harmful Algae 9: 163-172.

Scheffer, M. 1999. The effect of aquatic vegetation on turbidity; how important are the filter feeders? Hydrobiologia 408409: 307-316.

Sharifinia, M., Namin, J.I. \& Makrani, A.B. 2012. Benthic macroinvertabrate distribution in Tajan River using canonical correspondence analysis. Caspian J. Env. Sci. 10: 181-194.

Stumpf, R., Culver, M., Tester, P., Tomlinson, M., Kirkpatrick, G., Pederson, B., Truby, E., Ransibrahmanakul, V. \& Soracco, M. 2003. Monitoring Karenia brevis blooms in the Gulf of Mexico using satellite ocean color imagery and other data. Harmful Algae 2: 147-160.

Swift, S.A. \& Bower, A.S. 2003. Formation and circulation of dense water in the Persian/Arabian Gulf. Journal of Geophysical Research: Oceans (1978-2012) 108: 4-1-4-21.

Tester, P.A. \& Steidinger, K.A. 1997. Gymnodinium breve red tide blooms: Initiation, transport, and consequences of surface circulation. Limnol. Oceanogr. 42(5): 1039-1051.

Tomas, C.R. \& Smayda, T.J. 2008. Red tide blooms of Cochlodinium polykrikoides in a coastal cove. Harmful Algae 7: 308-317.

Trainer, V., Pitcher, G., Reguera, B. \& Smayda, T. 2010. The distribution and impacts of harmful algal bloom species in eastern boundary upwelling systems. Progress in Oceanography 85: 33-52. 
Moslem Sharifinia*

Young Researchers and Elite Club, Rasht Branch

Islamic Azad University, Rasht

Iran

Mohammadreza Mohammadpour Penchah

Young Researchers and Elite Club, Bandar Abbas Branch

Islamic Azad University, Bandar Abbas

Iran

Abolhasan Gheibi \& Rohallah Zare

Faculty of Science, Hormozgan University

P.O. Box: 3995, Bandar Abbas

Iran
Abbas Mahmoudifard

Faculty of Natural Resources, University of Guilan

P.O. Box: 1144, Sowmehsara

Iran

*Corresponding author; email: moslem.sharifinia@yahoo.com

Received: 13 August 2014

Accepted: 19 October 2014 